\title{
Terrorist Routes in Central Asia: Trafficking Drugs, Humans, and Weapons
}

\author{
Rustam Burnashev *
}

\section{Introduction}

The hypothesis around which this essay is structured is informed by the following questions:

- Are terrorists using the same routes as drug, human, and weapon traffickers?

- Are terrorists using drug, human, and weapon trafficking to support their activities?

The analytical basis for this article is a theory of a regional security complex. It may be viewed as a matrix for regional studies. It links the situation within regional states - including those in Central Asia that are addressed in this study - to relations among other states and international actors. It specifically looks at the interaction of regional states with neighboring states and world powers. ${ }^{1}$

It is very important to take into consideration two important factors. The first is that the states of Central Asia are weak states. The second is that Central Asia is an unstructured security region ${ }^{2}$ and a mini-complex. ${ }^{3}$ As such, it serves as an insulator ${ }^{4}$ between the regional security complexes of East Asia, South Asia, and the Middle East, as well as the security complex Russia is attempting to build around itself.

The situation in Central Asia can be best understood by dividing the countries of the region into two groups: "powerful" states and "weak" states. The categorization of weak and powerful states is determined by the degree of social and political unity between civil society and government institutions; the degree to which the state corre-

Dr. Rustam Burnashev is Professor at the Kazakh-German University in Almaty, Kazakhstan. For more on the regional security complex theory, see Barry Buzan, People, States and Fear: An Agenda for International Security Studies in the Post-Could War Era, 2nd ed. (Hemel Hempstead: Harvester Wheatsheaf, 1991); Barry Buzan, Ole Wæver, and Jaap de Wilde, Security: A New Framework for Analysis (Boulder, CO: Lynne Rienner, 1998); and Buzan and Wæver, Regions and Powers: The Structure of International Security (Cambridge: Cambridge University Press, 2004).

2 An unstructured security region is a region "where local states are so weak that their power does not project much, if at all, beyond their own boundaries, and so generate insufficient security interdependence to form the essential structures of a regional security complex." See Buzan and Wæver, Regions and Powers, 492.

3 A mini-complex is a "formation with the characteristics of a security complex, but small in scale and usually composed at least in part of substate actors." See Buzan and Wæver, Regions and Powers, 490.

4 An insulator is a "state or mini-complex standing between regional security complexes and defining a location where larger regional security dynamics stand back to back." See Buzan and Wæver, Regions and Powers, 490. 
sponds to a national identity; and the degree of cohesive statehood and stability (in terms of internal order) in the country. ${ }^{5}$

The type of state that is dominant in the region is the most significant factor that has influenced the routes of drug, human, and weapon trafficking researched for this paper. As mentioned previously, the states of Central Asia are weak. ${ }^{6}$ Generally speaking, states in the region are characterized by a low level of social and political cohesion, although it varies from state to state. Only a narrow social base of support for existing political regimes (particularly among the middle class) exists in these states. The vast majority of the population in the region is apathetic about politics. People tend to have weak ethnic identities, forcing them to develop alternate forms of identification. Despite a well-developed system of state repression (particularly in Uzbekistan and Turkmenistan), Central Asian countries commonly experience withdrawals from fullfledged expression of statehood - specifically, the central, national bodies have a tendency to serve as forums in which sub-state actors compete among themselves to ensure their own security or to exert influence over the country. The weaknesses associated with Central Asian states tend to keep states in the region relatively exposed to penetration by external forces. In addition, these forms of weakness allow sub-state actors to play a greater role in the determination of regional security and create power vacuums in which routes that can be used for trafficking drugs, humans, and weapons can flourish.

As mentioned above, Central Asia is both an "unstructured security region" and a "mini-complex" that serves as an "insulator" between other regional security complexes. Unsurprisingly, Central Asia also serves as transit zone for drug, human, and weapon trafficking. Afghanistan is a key to understanding the conditions that foster the manifestations of international terrorism that can currently be seen in the Central Asian region, as the security dynamics in Afghanistan and Central Asia are closely related. Therefore, some of the countries in the Central Asian "mini-complex" are particularly influenced by the security dynamics within Afghanistan. Moreover, most ties between Afghanistan and Central Asia are influenced by the inherent weakness of Central Asian countries and the fragmentation of Afghanistan. The links are created by sub-state and transnational actors, such as criminal syndicates involved with drug trafficking; ethnic and sub-ethnic groups; guerrilla and gang-related groups; and religious movements.

The research on which this essay is based relied on an analysis of open-source materials in the countries of Central Asia, including the media, official documents, academic research, and analytical papers.

See Buzan, People. States, and Fear, 96-107.

6 Rustam Burnashev and Irina Chernykh, "Conditions for Securitization of International Terrorism in Central Asia," Connections: The Quarterly Journal 4:1 (Spring 2005): 131-42. 


\section{Drug Trafficking}

\section{Drug Production in Central Asia}

Illegal drug production occurs in all Central Asian countries. Drug producers in the region mainly grow hashish and marijuana from wild Indian hemp. The primary cultivation areas include the Chu Valley, which is located in both Kazakhstan and Kyrgyzstan and encompasses approximately 170,000 hectares; and the Issyk-Kul district of Kyrgyzstan, which encompasses approximately 6,000 hectares. In addition, a vast quantity of "light" drugs are produced in Central Asia. Most output occurs in Kazakhstan, and Russia is the main consumer of these drugs.

In general, Thebaic poppies are illegally cultivated on small plots of land. This drug crop has a chaotic, irregular production cycle, and the product is intended primarily for domestic consumption within the region. Only a small amount of opium is produced due to the complex production process and the increasing volume of opium and heroin available from Afghanistan. In addition, some narcotics are hand-produced (ephedra, which is made using wild hemp, is an example).

It is necessary to note that the industrial production of semi-synthetic drugs is increasing in Central Asia, especially in Kazakhstan. Shymkent, Kazakhstan, for example, is home to a factory for producing morphine, codeine, and other opiates.

\section{Drug Importation and Transit}

Central Asia's geographical proximity to Afghanistan is the most important factor affecting regional drug trafficking. Approximately 30 percent of the drugs produced in Afghanistan - an annual average of 120 tons or more, primarily heroin - are transported through Central Asia. In addition, the disintegration of the Soviet Union, the civil war in Tajikistan, and the struggle against the illicit drug trade in Iran have created conditions resulting in increased drug trafficking through Central Asia. In general, drug transit occurs over the borders between Afghanistan, Tajikistan, and Turkmenistan.

Factors that affect drug smuggling in the region and promote drug transit in Central Asian countries include the long common border between Afghanistan and the countries of Central Asia and the increase in demand for narcotics in Central Asia and Russia. Drug trafficking routes in the region tend to connect settlements and pass along common transportation corridors. ${ }^{7}$ These routes will be outlined below.

\section{Tajikistan}

Presently, drug trafficking from Afghanistan to Tajikistan proceeds through areas bordering the following settlements: Shuroabad, Moskovskiy, Panj, and Shaartuz. These areas have relatively flat topography and well-developed transportation corridors. Drug transit occurring in limited volumes is still carried out through the Gorniy-Badakshan

7 See Leonid Bondarets, "Empire of Drugs," in Illicit Markets of Central Asia (Nelegal'nyy rynok Tsentral'noy Azii) (Almaty: ARG, OSCE, EC), 8-40 (in Russian). 
Autonomous Viloyati (Ishkashim, Khorugh, and Kalaihum). ${ }^{8}$ The main settlements through which drug transit in Tajikistan flows are Kulob, Qurghonteppa, Dushanbe, and Khujand.

Narcotics from Khujand transit through Bekabad to Uzbekistan, and across the Batken district to Kyrgyzstan. Since 1998, evidence suggests that the drugs transiting through Murgab are destined for China. In fact, the Dushanbe airport is very actively used for drug transit.

Kyrgyzstan

Narcotics from Tajikistan mainly come into Kyrgyzstan from four directions:

- Across the Khorugh-Osh border

- Through the area spanning the canyons of Pamir and the Zaalayskiy mountain range to the Alayskaya valley of the Osh region

- Across the Jirgatal mountain trails and other neighboring areas of Tajikistan through Batken and Kadamzhaisk

- Via the Khujan main roads to the Batken region and Ferghana valley of Uzbekistan and on to Osh.

\section{Uzbekistan}

Narcotics from Afghanistan transit into Uzbekistan through Termez. Drug smuggling from Tajikistan is carried out through:

- The settlements of the Surkhondaryo region

- The neighborhoods of the Namangan area

- The Almalyk, Bekabad, Buka, and Yangiabad neighborhoods of the Tashkent region

- The Bakhmal and Zaamin neighborhoods of the Jizzakh district

- The Khavast neighborhood of the Sirdaryo region.

Drugs smuggled from Kyrgyzstan enter Central Asia through Andizhan and the Namangan district. Through the Ferghana province, drug transit occurs from the Batken and Osh districts of Kyrgyzstan. According to official representatives of Turkmenistan, most drugs are transited to Uzbekistan from the Lebap region.

\section{Turkmenistan}

Narcotics mostly come into Turkmenistan from Afghanistan and, to a lesser degree, from the Khorazm district of Uzbekistan. The transit of narcotics from Afghanistan to Turkmenistan tends to follow these routes:

8 This route has become inactive because of the activity of the "Pamir Antinarcotics Volunteers Association," which was established by the "Osh Knot" Project and Aga Khan Foundation. 
- Through the checkpoints at Gushgy and the Takhta Bazar of the Mary district

- Through the checkpoint at Imamnazar in the Lebap district.

Narcotics transit through the port at Turkmenbashi and subsequently go to Astrakhan and Azerbaijan. Narcotics also transit through Turkmenistan to Uzbekistan and Kazakhstan, with the Ashgabat airport being one of the most important points of transit.

\section{Kazakhstan}

Narcotics smuggled into Kazakhstan primarily come from the bordering country of Kyrgyzstan. This border is, for all practical purposes, completely open, and the entire perimeter is thus a prime location for trafficking. Cannabis tends to come from Karakol in Kyrgyzstan and transit through to Almaty. This route makes use of mountain passes and the Chu River as well as the border between Bishkek and Almaty. Opiates tend to enter from the Lebap region of Turkmenistan through Karakalpakstan and on to western Kazakhstan. The main drug trafficking routes pass through southern, central, and western Kazakhstan. From there, they enter Russia, ultimately destined for Europe. In most cases, the routes follow basic lines of transportation and communication. Synthetic narcotics tend to flow in the opposite direction; they come from Western Europe to Kazakhstan, and then transit through to China.

Analysis of the main routes of narcotics trafficking has revealed the primary Central Asian markets for drugs, which are characterized by large settlements of people and locations in border areas. The most important such markets are Dushanbe and Khudjand in Tajikistan; Osh and Bishkek in Kyrgyzstan; Tashkent in Uzbekistan; and Almaty in Kazakhstan.

\section{Human Trafficking}

The fundamental factors influencing human trafficking in Central Asia are low living standards and unemployment, especially in Tajikistan, Uzbekistan, and Kyrgyzstan. In addition, the unstable economic and political situations and various ethnic problems within Central Asian countries impact the migration process, both within the region and from the outside. The main migration stream from Central Asia is directed toward Russia and Kazakhstan. Migrants from China, particularly, are destined for Kazakhstan.

There is some evidence that citizens of Central Asian countries are departing the region for South Asia and the Middle East. After passing through radicalized religious centers and training camps, some of them become members of terrorist groups. Refugees from Uzbekistan and Tajikistan have particularly added to the manpower of terrorist organizations.

Central Asian states are also transit zones for migrants from China, Afghanistan, Turkey, Pakistan, and other South Asian countries. Migrants usually do not have the appropriate legal status, and many pass through the region illegally. 


\section{Weapons Trafficking}

Automatic rifles are the main weapons that are present in the Central Asian illegal arms market. Most of the illegal arms available in Central Asian states are either diverted from the military; transported illegally from abroad; stolen from plants producing ammunition and weapons; or individually owned (and sometimes homemade) weapons used for hunting.

The civil wars in Tajikistan and Afghanistan have only increased the dissemination of illegal arms in Central Asia. Criminal groups are the main arms buyers, while military structures with access to unaccounted arms and ammunitions are the primary sellers. In addition, people connected to the production and maintenance of arms and ammunition are a considerable source of illegal arms dissemination.

\section{Conclusion}

The idea that terrorists are using the same routes as arms, drug, and human traffickers is complicated. Currently, there are no indisputable data indicating that terrorists and terrorist groups are transiting across Central Asia. However, if this activity does exist, terrorist groups may be using trafficking routes to penetrate Central Asian countries.

Terrorists and criminals are benefiting from transparent borders in the region, which are the result of a general lack of law enforcement and regional security. The relationship between terrorism and human trafficking in Central Asia is evident, and has been verified through data in this volume.

Most likely, terrorist groups use arms and drug trafficking primarily to finance their activities. Financially, terrorists and drug, human, and weapon traffickers are benefiting from the unregulated "shadow" economy and high levels of corruption in Central Asian countries. 
SPRING 2007

\section{Bibliography}

Bondarets, Leonid. "Empire of Drugs." In Illicit Markets of Central Asia (Nelegal'nyy rynok Tsentral'noy Azii), 8-40. Almaty: ARG, OSCE, EC, 2002.

Buzan, Barry, and Ole Wæver. Regions and Powers: The Structure of International Security. Cambridge: Cambridge University Press, 2004.

Buzan, Barry, Jaap de Wilde, and Ole Waeve. Security: A New Framework for Analysis. Boulder, Colorado: Lynne Rienner Publishers, 1998.

Buzan, Barry. People, States and Fear: An Agenda for International Security Studies in the Post-Could War Era. 2nd ed. Hemel Hempstead: Harvester Wheatsheaf, 1991.

Chernykh, Irina, and Rustam Burnashev. "Conditions for Securitization of International Terrorism in Central Asia." Connections: The Quarterly Journal 4, no. 1 (2005): 131-142. 